\title{
Leadership's Policy in Pandemic School Era: New Student Admission, Zonation System, and Digital Problem
}

\author{
Samsu* \\ Universitas Islam Negeri Sulthan Thaha Saifuddin, Jambi \\ *corresponding author: samsu@uinjambi.ac.id
}

\begin{abstract}
:
This study discusses the leadership of school principals in the context of new student admissions by zonation system, and tracking digital problems in the pandemic era. This study aims to analyze how technology responds to policies related to new student admissions in the Covid-19 era. A qualitative approach is used. researcher as an active instrument. Data related to leadership policies, intake of new students, and digital problems were obtained through interviews, observations, and documentation with data flow chart analysis by Miles and Huberman. The findings show that the acceptance of new students at MAN 2 Jambi City takes into account the number of teachers, and facilities according to the on-line PPDB technical instructions. The on-line 2020/2021 $P P D B$ acceptance is intended to apply 2 channels, namely the "general route and achievement (zonation system)" connected to the databases of the ministry of social affairs, the ministry of education, and the ministry of religious affairs to avoid fraud. Research also proves that the digital problem in this madrasah does not occur. It is recommended that the on-line PPDB implementation be carried out through a zonation system.
\end{abstract}

KEYWORDS: Leadership; new student admission; zonation system.

\begin{abstract}
ABSTRAK:
Penelitian ini membahas tentang kepemimpinan kepala sekolah dalam konteks penerimaan siswa baru dengan sistem zonasi, dan melacak masalah digital di era pandemi. Penelitian ini bertujuan untuk menganalisis bagaimana teknologi merespons kebijakan terkait penerimaan mahasiswa baru di era Covid-19. Penelitian ini menggunakan pendekatan kualitatif dengan peneliti sebagai instrumen aktif. Data yang terkait dengan kebijakan kepemimpinan, penerimaan siswa baru, dan masalah digital diperoleh melalui wawancara, pengamatan, dan dokumentasi dengan analisis grafik data oleh Miles dan Huberman. Hasil penelitian menunjukkan bahwa penerimaan siswa baru di MAN 2 Kota Jambi memperhitungkan jumlah guru, dan fasilitas sesuai dengan petunjuk teknis PPDB online. Penerimaan PPDB online 2020/2021 dimaksudkan untuk menerapkan 2 jalur, yaitu "jalur umum dan prestasi (sistem zonasi)" yang terhubung dengan database kementerian sosial, kementerian pendidikan, dan kementerian agama

Copyright (c) Published by Program Studi Manajemen Pendidikan Islam Fakultas Tarbiyah dan Keguruan

Universitas Islam Negeri Sulthan Thaha Saifuddin jambi Mendalo Darat, Muaro Jambi, 36361, Indonesia
\end{abstract}


untuk menghindari penipuan. Penelitian juga membuktikan bahwa tidak terjadi masalah digital di madrasah. Pelaksanaan PPDB online disarankan dilakukan melalui sistem zonasi.

KATA KUNCI: Kepemimpinan; penerimaan siswa baru; sistem zonasi

\section{INTRODUCTION}

The leadership's policy in accepting new students since social distancing was implemented in the Covid-19 era has given a signal to digital technology whose benefits are widely questioned. Digital technology is considered to damage the existence of education and civilization. The technological content contained in it has damaged the human civilization built by education. So far, studies on leadership policies have paid less attention to technological aspects in the context of their use in new student admissions with a zonation system. In contrast to existing research, this research explains practically the role of technology that has been denied to be something that can be accepted as an inseparable part in the context of education. The purpose of this paper is to complement the shortcomings of using technology for leadership by analyzing how technology answers the needs of leadership policies related to new student admissions in the Covid-19 era. This paper is based on the argument that technology is not only useful for leadership, but is a solution in accepting new students in schools and as the beginning of the transformation of education into the digital era.

Previous studies related to leadership's policy focused more on the zonation system. (Andina, 2017); (Purwanti, 2019) for example discussed the zonation system and psychosocial impact to the student, beside the implementation of new student admission policy by zonation system in the city of Bandung. Researchers have yet to attempt to link leadership's policy to new student admission, zonation system, and digital problem in pandemic school era.

Dynamics is a movement or group strength owned by the community that can cause changes in the structure of the community's life in question, while the dynamics of the principal's leadership is a way of guiding, so it can be concluded here that the meaning is the power possessed by the principal's leadership with the administrative or management power he has in order to 
change the system. New student admissions in the pandemic era with the student zonation system at MAN 2 Jambi City went smoothly. Admission of new students through the zonation system is regulated through the Ministry of Education and Culture Regulation No. 17/2017 in conjunction with the Ministry of Education and Culture Regulation No. 18/2018 and applies to all the ministry of education and culture in the district/ city levels throughout Indonesia. New Student Admissions are kindergarten, elementary and junior high schools which are held at the beginning of the new school year. New student admission or penerimaan peserta didik baru (well-known PPDB) for junior high school is done online, the priority is for children aged 12-15 years. Especially madrasah in Jambi City such as public/private MI/MTs/MAs do not use the zonation system as applied to public/private elementary/junior high schools, so the implementation of New Student Admission at MAN 2 Jambi City is carried out freely from anywhere. The procedure for implementing the PPDB at MAN 2 Jambi City in the pandemic era is to use a registration system through the network, or called the online system. This system is effective because this system is implemented during the pandemic to avoid physical contact and crowds of prospective students who will register at school. This dynamic used by the principal as a leader is considered the most appropriate and does not violate the health protocol rules implemented by the government from the center to the regions.

In fact, the dynamics applied by the principal and the administration of new student admissions in this pandemic era are often not accepted or considered detrimental to prospective new students or there is a rejection or contra of policies, because the guardians of students do not master the communication technology system which is considered new and unfamiliar to students, so it is difficult for them. Furthermore, this policy was accepted with a mindset that already disagreed with various reasons such as a lot of less accurate information and more negative provocations that are often received by our society. Then the zonation system is considered not in favor of quality children but does not have the freedom to choose their favorite school, because the desired school already has a good name in the city even though if viewed from the distance it is quite far from where they live, this is what makes the problem of not finding the zonation system. 
It can be concluded that the zonation system implemented in MAN 2 Jambi City is still very flexible and this is what we call the dynamics of principal leadership \& admission of new student administration in the pandemic era, because this school does not directly implement policies that have been issued by the government, but more adapted to the conditions of Jambi City.

Understanding the concept of leadership is very useful for school principals in carrying out their role as educational leaders. The principal functions as a personal, educator, manager, administrator, supervisor, social, leader, entrepreneur, and climator (PEMASSLEC) (Latri, 2017). The dynamics of the principal's leadership cannot be separated from his role as a principal, he must have intelligence above the average of his subordinates to develop nine educational leadership intelligences, namely ethical, spiritual, contextual, operational, emotional, collegial, reflective, pedagogic, and systematic intelligence. In addition to requiring intelligence above the average of his subordinates, principals also need effective leadership or leadership behavior in carrying out their roles. An effective leader is a true leader to carry out the administration of school education.

School administration, especially students, must be supported by good planning, especially when it comes to accepting new students until their graduation. Technological developments, especially in the acceptance of new students, have a very strong impact on the complexity of the management of new student admissions on the one hand. In addition, information technology is increasingly needed by educational institutions, especially in increasing the smooth flow of information in educational institutions, controlling quality, and creating alliances with other parties that can increase value for the school on the other hand. Even Gunawan stated that "PPDB is an activity of accepting and selecting prospective students at a school. This selection is related to academic ability and talent, interest in the level of education towards the desired goal (Gunawan, 2017).

New Student Admission is an academic selection process for prospective students to go to a higher level of education. PPDB with all its systems, is carried out to find out and measure school inputs to help school development and is expected to make a high contribution in planning and implementing educational and learning activities in the future (Sholihin, 2014). 
Admission of New Students who are familiar with the PPDB acronym is an annual routine activity which is the selection stage for prospective new students organized by a school-level committee under the supervision and coordination of the Ministry of Education and Culture.

PPDB online is a system designed to perform selection automatically starting from the registration process, selection to selection announcements which are carried out online (Sari, 2016). Based on the Regulation of the Minister of Education and Culture of the Republic of Indonesia Number 14 of 2018 concerning the acceptance of new students in Kindergarten (TK), elementary school (SD), junior high school (SMP), senior high school (SMA), vocational high school (SMK) or other equivalent forms. This is in line with article 4 paragraph 3 which states that implementation is prioritized using online mechanisms. In Mulyasa's view (2004) student management is the arrangement and regulation of activities related to students, from entry to exit of these students from a school. Student management is not only in the form of recording student data, but includes broad aspects that operationally can help efforts to grow and develop students through the education process in schools.

Mulyasa (2004) understands that student management is directed at the goal of regulating various student activities so that learning activities in schools can run smoothly, orderly, and regularly, and achieve school education goals. In realizing these goals, student management must at least have three main tasks that must be considered, namely acceptance of new students, learning progress activities, as well as guidance and discipline (Mulyasa, 2004).

1. Analysis of new student acceptance

Before carrying out the activity of accepting new students, at each level of formal education, first conduct an analysis of the needs of students. In carrying out the analysis process, the main consideration is the class capacity or the number of available classes, in the sense that the ratio of teaching staff to students in one class can be balanced in accordance with applicable policies. The activity of analyzing the acceptance of new students is to plan the number of students to be accepted, namely the capacity of schools and classes, the ratio of students and teachers which aims to compare the number of students and teachers to be balanced and arrange a program of student activities, including the vision, mission and 
goals of the school interests, talents of students, facilities and infrastructure, available budget and available educational staff.

2. Student admission policy

The student admission policy states that "The student admission policy is related to the use of the basics of student management so that someone is accepted as a student in a school, prospective students must meet the requirements as determined. The operational policy of new student admissions contains rules regarding the number of students that can be accepted in a school (Purwanti, 2019). The determination of the number of students, of course, is also based on the realities that exist in the school (school conditional factors). These conditional factors include: the capacity of the new class, criteria regarding acceptable students, available budget, existing infrastructure and facilities, available educational staff, number of students living in first grade, and so on (Mutiarin, 2017).

3. New student admission system

The new student admission system is a mechanism for accepting new students (Latri, 2017). There are two kinds of new student admission system. First, by using a promotion system, while the second by using a selection system (Latri, 2017). What is meant by the promotion system is the acceptance of new students, previously without using selection. Those who register as prospective students in a school, are taken for granted. So that those who register as prospective students, no one is rejected. This promotion system generally applies to schools whose enrollment is less than the specified quota or capacity. Second, is the selection system. This selection system can be classified into three kinds. First, the selection is based on the list of National Final Examination (UAN) scores, the second is based on the Interest and Ability Search (PMDK), while the third is based on the entrance test. With the benefits and convenience of existing technology, the development of the New Student Admissions (PSB) information system should be developed by each school.

4. Criteria for acceptance of new students

Criteria are benchmarks that unite whether or not a person can be accepted as a student. There are three kinds of student acceptance criteria. 
First, is the standard criteria referenced, which is an acceptance of participants based on the standard. Pre-determined benchmarks. In this case, the school first makes a benchmark for prospective students with a minimum ability at the same level as the school that accepts students. As a consequence of the acceptance that is based on criteria, if all prospective students who take part in the selection meet the minimum criteria specified then they must be accepted by all. Conversely, if prospective students who register do not meet the minimum standards that have been determined, the students will be rejected or not accepted.

5. Procedure for accepting new students at MAN 2 Jambi City

According to Imron (2011), the procedures for accepting new students are the formation of a new student admissions committee, a meeting to determine new students, making, posting or sending announcements, registration of new students, selection, determination of new students accepted, announcements of students who are accepted. accepted and registration of students who are accepted and registration of students who are accepted (Imron, 2011).

The procedures for accepting new students at MAN 2 Jambi City are as follows:

a. Via public route

1. Online registration that has been prepared by the committee by entering the full name, names of parents, address, and school or madrasa origin.

2. The collection of files/materials is carried out directly to MAN 2 Jambi City, while the materials collected are as follows: 1) Graduation Certificate, 2) Report Card for 5 semesters, 3) Family card, 4) Birth certificate, 5) Photocopy of Card Smart Indonesia (if yes), 6) Photocopy of school accreditation, 7) Certificate of parental responsibility, 8) Passport photo 334, 9) Certificate of being able to read and write the Qur'an, 10) Print out Verbal NISN from home school.

3. Selection test, the test method carried out is through the internet network, using the WhatsApp application. The test process is that prospective students are called on the phone first, with being reminded to prepare themselves, because in 15 minutes they will be 
called by video call, while the form of the test by video call is a written test by being given questions about general knowledge, religious knowledge, reading and writing tests of the Qur'an. an, and psychological test.

b. Through the Achievement Path

The difference between the achievement test and the general route is for the achievement track when collecting materials by adding a certificate or certificate of achievement while in SMP/MTs and Islamic boarding schools. Then for the achievement path there is no test. Thus, students are accepted directly by re-registration. Next is the announcement of the test results online and those who pass immediately re-register.

\section{METHODS}

This study uses a qualitative approach which is intended to gain a broader and deeper understanding of the data found (Moleong, 2014). The reason this research uses a qualitative approach is because this research is not concerned with numbers, but describes clearly and in detail and empirically obtains in-depth data from the research focus. In this study, researchers act as data collectors and as active instruments in an effort to collect data in the field, while other data collection instruments besides humans are various forms of data collection in the form of interview guidelines, observation guidelines, and documentation guidelines that can be used to support the collection process. data from research. In this study, researchers collected data by conducting interviews with informants such as the principal, deputy principal, student affairs, administration, and school operators. In addition, researchers made observations by observing related to the implementation of online-based student admissions. The location where the research was conducted in MAN 2 Jambi City. To obtain the data or information needed in answering the problems studied in the study, it is necessary to have a subject or research informant. In this study, the research subjects were the head of MAN 2 Jambi City and the deputy head of the student affairs department and school operators as informants. 
Data collection techniques, namely interviews, documentation and observation. Data analysis is an activity after data from all respondents or other data sources are collected. After all the data has been collected, the next step taken by the researcher is to process the data or it can be called data analysis (Sugiyono, 2012) stating that data analysis is the process of systematically searching and compiling data obtained from interviews, field notes, and documentation, with how to organize data into categories, break it down into units, synthesize it. Arrange into patterns, choose what is important and what will be studied, and make conclusions so that they are easily understood by themselves and others (Riyanto, 2007). The data validity test carried out in this study is known as "data triangulation" which is a technique for checking the validity of data that uses something else. With data triangulation, researchers can check their findings by comparing them with various sources, methods or theories that can be done by asking various kinds of questions, checking with various data sources, and using methods so that checking the reliability of the data can be done. There are three stages of research and the last stage of research is the writing of research reports (Sugiyono, 2012). The stages of the research are 1) the pre-research stage, some of which need to be prepared by the researcher, and compiling a research design in the form of questions to be asked to informants in the field, 2) the research stage, which includes collecting materials related to student admissions, 3) the data analysis stage, including the analysis of good data obtained through in-depth interviews with the principal and teachers, 4) the report writing stage, including: activities of compiling research results from all series of data collection activities to giving meaning to the data.

\section{FINDINGS AND DISCUSSION}

Broadly speaking, the results of the research that have been obtained through the interview and documentation process show that at the analysis stage of the acceptance of new students, there are several considerations, namely looking at the availability of learning classes for students and the ratio between teachers and students. In line with the results of the study, according to providing information that, what is included in the analysis of new student admissions is planning the number of students to be accepted, namely the capacity of schools and classes, the ratio of students and teachers which aims to compare the number of students and teachers can be balanced formulate a 
program of student activities, including the vision, mission and goals of the school, interests and talents of students, facilities and infrastructure, available budget and available educational staff.

The implementation of on-line-based new student admissions management at MAN 2 Jambi City in determining the capacity in 1 group has been determined objectively, where the accepted capacity is 406 and 12 groups. One group has a capacity of 35 students, this has been determined by government policy, namely the Regulation of the Minister of Education and Culture of the Republic of Indonesia No. 17/2017 concerning "Acceptance of New Students in Kindergarten, Elementary School, Junior High School, Middle School. Senior High School, Vocational High School, or Other Equivalent Form Article 24 "that is, SMK in one class has a minimum of fifteen students and a maximum of thirty-six students.

The results of the research findings as a whole are that the number of students in 1 group consists of $35-36$ students, this is the same as government policy related to the determination of groups in SMK, namely 35-36 in 1 group. However, the researchers found that the ratio of teachers and students was very far. Where the number of teachers is only 89 teachers and as many as 1177 students. We can know from the results of interviews, observations and documentation that the ratio between teachers and students is not balanced. This has been reinforced by the results of the documentation in the form of a decree on teacher teaching hours and data on the number of students.

Policy for online-based student admission. Based on the results of research that has been compiled, it shows that the online-based student admission process is carried out, guided by the Indonesian Government Regulation number 17 of 2010 "On the management and administration of education, article 82 paragraph 1 " of student acceptance in secondary education units. carried out in an objective, transparent and accountable manner. In regulation number 17 of 2010, PPDB Online aims to ensure the acceptance of new students is objective, transparent, accountable, non-discriminatory and fair in order to encourage increased access to education services. In addition to referring to policies that apply nationally in the process, there are guidelines made by the Ministry of Education and Culture in Jambi City. This technical guideline is the guideline in the implementation of online-based new student 
admissions. Which stipulates several operational policies in their implementation as technical steps for activities, starting from the registration process, determining criteria, to announcement of selection results. This is done to facilitate the selection of prospective students as expected. In line with the results of the study, this new student admission policy was made based on the instructions given by the district/city education office. Such instructions must be guided, because they are indeed made in order to get prospective students as desired or idealized. The results that the researchers found were that the school's policies included determining the number of students accepted and the place of registration for prospective students who were set in the teacher's meeting room and the budget for implementing online student admissions came from the School's BOS funds.

The system for online-based new student admissions at MAN 2 Jambi City has 2 admission systems, first, the Achievement track, the Achievement Track is a registration path for prospective new students who have achievements in academic and non-academic competitions who are domiciled outside the nearest zone of the school. Second, the affirmation path, namely the Affirmation Path, is a registration path for prospective new students who come from economically disadvantaged families and are domiciled in the nearest zone radius from the school. Furthermore, there is what is said to be a special path called a special path, namely the registration path for prospective new students with special reasons, including changing the domicile of parents/guardians or natural/social disasters living outside the nearest radius zone from the school. on each of these paths have been determined the quota of each lane. The Achievement track has a quota of $5 \%$ specifically $5 \%$ affirmation $20 \%$ while $70 \%$ academic as stated by Latri (2017), namely this selection system can be classified into three types. First, the selection is based on the list of National Final Examination (UAN) scores, the second is based on the Interest and Ability Search (PMDK), while the third is the selection based on the entrance test results. The selection system with Interest and Ability Tracing (PMDK) is carried out by thoroughly observing the students in previous schools (Latri, 2017).

The results of the research are the theory of the new student admission system, which is the same as the system applied in MAN 2 Jambi City, namely selecting by looking at the results of the National Final Examination (UAN) 
MAN 2 Jambi City applying the Academic pathway system and affirmations. The selection based on interest and ability tracking (PMDK) looks at the achievements or abilities possessed by new prospective students where this path is called the Achievement track and the selection system with Interest and Ability Tracking (PMDK) is carried out by observing thoroughly the students at the previous school where the special path looks at the school or residence of the previous prospective students.

Criteria are benchmarks that unite whether or not a person can be accepted as a student. There are several requirements or criteria that must be given by prospective students in each path. However, the criteria given by prospective students, In determining the criteria for requirements for prospective students, there are various views from each path. Standard criterian referenced is an acceptance of participants based on a standard. Predetermined benchmarks. Second, norm criteria-referenced, namely the acceptance of prospective students based on the overall achievements of prospective students who take part in the selection. And third, the criteria based on the school's capacity, the school first determines how many OnlineBased New Student Admission Management Implementations at the Jambi City MA Model the amount of capacity, or how many prospective new students will be accepted.

Basically, a good acceptance procedure is a procedure that is easy and can be understood by the enthusiasts (Wintoko, 2016). We already know that the admission procedure is online based, starting from registration and data verification of prospective students who register to re-registration for prospective students who are accepted (Wintoko, 2016). The procedure for accepting new students is online announcements in the form of billboards around the school so that students can clearly announce the acceptance of new students from the schedule to the predetermined requirements. In online PPDB registration, students must open the online PPDB site to register online. After registration has been completed, the committee immediately verified the data of students who registered. Furthermore, after the registration, there is an announcement stage, namely Announced simultaneously, directly, transparently, and accountable through the online PPDB Application on the "manmodelkotajambi.go.id" page at the time of the announcement of student graduation, the school has also attached the names that have passed at MAN 2 
Jambi City along with the announcement of the time for re-registration for students who have passed.

\section{CONCLUSION}

Based on the findings and analysis of the research conducted, it can be concluded that: The implementation of PPDB Online in the 2020/2021 academic year of MAN 2 Jambi City is guided by the Jambi Governor's Decree and the acceptance system implemented in MAN 2 Jambi City, namely 2 of them, through public channels and through public channels. performance. Selection on online PPDB is currently connected directly to the databases of the Social Service, Education Office, and Ministry of Religion. The procedure for accepting new students, namely the online PPDB, is currently more transparent and makes it easier for students and the committee to verify the actual data, and the accountability of the committee is easier because all data has been using an online system. Some of the reasons students choose MAN 2 Jambi City is because of the assumption that MAN 2 Jambi City is one of the MAN in Jambi Province that has good achievements compared to MAN in Jambi Province, besides that it is close to the area where students live. students who come from Islamic boarding schools and MTs, the reason they choose MAN 2 Jambi City, is because scientifically, the knowledge is linear and continuous from the basis of religious knowledge. As for the cause of the child not graduating, it was due to not being able to meet the requirements set by the selection committee for new student admissions, including; report cards that do not meet the standards set by the committee, cannot answer the knowledge of the basics of religious science, and the basics of reading and writing the Qur'an.

\section{PRACTICAL IMPLICATIONS}

Based on the findings on new student admissions at MAN 2 Jambi City, it is proven that online admissions are very effective and the principal's decisions are in accordance with the policies decided by the Governor and the center in the online system in the pandemic era and the concerns of parents of students having difficulties in the zonation system are not proven in the system. which is applied in MAN 2 Jambi City. 


\section{REFERENCES}

Andina, E. (2017). "Sistem zonasi dan dampak psikososial bagi peserta didik." Majalah, Info Singkat Kesejahteraan Sosial.

Gunawan, I. (2017). Manajemen Pendidikan. Bandung: Alfabeta.

Imron, A. (2011). Manajemen Peserta Didik Berbasis Sekolah. Jakarta: Bumi Aksara.

Kompri. (2015). Manajemen Pendidikan. Bandung: Alfabeta.

Latri, W. (2017). "Evaluasi Program Penerimaan Peserta Didik Baru (PPDB) Dengan Sistem Real Time Online." Jurnal Hanta Widya, 5(9).

Mulyasa, E. (2004). Manajemen Berbasis Sekolah, Konsep, Strategi dan Implementasi. Bandung: Rosdakarya.

Mutiarin, D. \&. (2017). "Evaluasi Penerapan Siap-PPDB Online dalam Meningkatkan Mutu Online Siap-PPDB Evaluation Toward Educational Services Quality." Jurnal Penelitian Pers dan Komunikasi Pembangunan.

Purwanti, D. I. (2019). "Implementasi Kebijakan Penerimaan Peserta Didik Baru Berdasarkan Sistem Zonasi di Kota Bandung." Jurnal Governansi, 5(1).

Samsu. (2017). Metode Penelitian Teori dan Aplikasi Penelitian Kualitatif, Kuantitatif, Mixed Methods, Serta Research \& Development. Jambi: Pusaka.

Sari, A. U. (2016). "Efektivitas Penerimaan Peserta Didik Baru (PPDB) Melalui Sistem Penerimaan Peserta Didik On-line." Prosiding, Profesionalisme Pendidik Untuk Membangun Anak Bangsa. Graduate School Conferences, Universitas Negeri Malang.

Sholihin, M. \&. (2014). "SholihinSistem Penerimaan Peserta Didik Baru Berbasis Web (Online) di SMK Muhammadiyah 7 Kedungpring Lamongan." Jurnal Penelitian Teknik Listrik dan Mekatronika, 557 -560 .

Sugiyono. (2012). Metode Penelitian Kuantitatif Kualitatif dan RED. Bandung: Alfabeta.

Wintoko, A. (2016). "Implementasi Pelayanan Publik Program Penerimaan Peserta Didik Baru Melalui Sistem Online (Studi di SMAN 1 Banyuwangi dan SMAN 1 Singojuruh Kabupaten Banyuwangi)." Jurnal Administrasi Publik (JAP), 4(4). 